\title{
KEPEMIMPINAN KEPALA SEKOLAH DI MADRASAH IBTIDAIYAH NEGERI (MIN) KILONGAN KECAMATAN LUWUK KABUPATEN BANGGAI
}

\author{
Oleh : Hasrat Aimang
}

\begin{abstract}
Abstrak
Dalam penelitian ini diterapkan metode analisis kuantitatif dengan pendekatan yang bersifat sosiologis / empiris, dengan maksud hanya sekedar memberikan gambaran dari masalah kepemimpinan kepala sekolah di Madrasah Ibtidaiyah Negeri (MIN) Kilongan.

Hal ini ditentukan oleh adanya peran yang baik dari Kepala Sekolah dengan menjalankan semua fungsi dan tugasnya sebagai pemimpin (leadership) serta sebagai pengelola (manajerial) di Madrasah Ibtidaiyah Negeri (MIN) Kilongan, sehingga mutu pendidikan di sekolah tersebut menjadi semakin baik sesuai dengan tujuan yang diharapkan dan adanya program-program penunjang mutu pendidikan yang dibuat Kepala Sekolah di Madrasah Ibtidaiyah Negeri (MIN) Kilongan.

Berdasarkan hasil penelitian yang telah dipaparkan mengenai kepemimpinan Kepala Sekolah di Madrasah Ibtidaiyah Negeri (MIN) Kilongan yang ditinjau dari tiga aspek kemudian penulis jabarkan dalam tabel berikut yang hasilnya merupakan kesimpulan dari keseluruhan aspek yang dikaji mengenai kepemimpinan Kepala Madrasah Ibtidaiyah Negeri (MIN) Kilongan adalah "sangat memuaskan" dengan angka skor rata-rata 4,85. Angka tersebut memberi makna bahwa $97 \%$, atau 17 dari 18 orang responden yangmenyatakan bahwa kepemimpinan kepala sekolah di Madrasah Ibtidaiyah Negeri (MIN) Kilongan yang ditinjau dari tiga aspek adalah "sangat memuaskan".
\end{abstract}

Kata kunci : Kepemimpinan, Kepala Sekolah

\section{PENDAHULUAN}

\section{Latar Belakang Masalah}

Peranan kepala sekolah pada saat ini semakin bertambah setelah pemerintah menetapkan pelaksanaan otonomi daerah dimana aspek pendidikan mendapatkan peranan yang sangat penting terutama tanggung jawab terhadap kemajuan di bidang pendidikan. Tentunya untuk mengemban tugas-tugas tersebut adalah tidak mudah karena pendidikan itu mempunyai masalah dalam komunikasinya, khususnya di Indonesia sebagai negara yang sedang berkembang senantiasa mengaitkan aspek pendidikannya dengan modernisasi.
Dalam hubungan tersebut di atas dapat dilihat suatu fakta dalam menghadapi tantangan modernisasi, dimana kepala sekolah sebagai pengemban tugas pendidikan nasional sebagai pemeran yang utama dalam rangka pelaksanaan manajemen berbasis sekolah. Menurut E. Mulyasa (2003 : 126) bahwa :

"kepemimpinan kepala sekolah yang efektif dalam manajemen berbasis sekolah dapat dilihat berdasarkan kriteria berikut : Pertama Mampu memberdayakan guru-guru untuk melaksanakan proses pembelajaran dengan baik, lancar, dan produktif; kedua Dapat menyelesaikan tugas dan pekerjaan sesuai dengan waktu yang telah ditetapkan; ketiga Mampu 
menjalin hubungan yang harmonis dengan masyarakat sehingga dapat melibatkan mereka secara aktif dalam rangka mewujudkan tujuan sekolah dan pendidikan; keempat Berhasil menerapkan prinsip kepemimpinan yang sesuai dengan tingkat kedewasaan guru dan pegawai lain di sekolah;kelima Bekerja dengan tim manajemen; keenam Berhasil mewujudkan tujuan sekolah secara produktif sesuai dengan ketentuan yang telah ditetapkan."

Sekolah adalah suatu lembaga pendidikan sebagai tempat guru mengajar dan murid belajar, suatu tempat dimana proses belajar mengajar dilangsungkan. Hasil dari proses ini diharapkan setiap peserta didik dapat menguasai, meningkatkan dan bahkan mengembangkan ilmu pengetahuan, teknologi, seni, kepribadian dan pandangan hidup serta tata pergaulan sesama manusia dan hasil karyanya.

Peranan kepala sekolah sebagai pemimpin di sekolah dimaksudkan untuk menciptakan kemajuan prestasi belajar peserta didik; karena itu peran sebagai pelaksana manajemen berbasis sekolah dipandang sebagai faktor mutlak untuk dilaksanakan guna perkembangan pendidikan. Akan tetapi peranan kepala sekolah tersebut di atas kadang kala dalam tataran aplikasinya jauh daripada yang diharapkan.

Demikian halnya di Madrasah Ibtidaiyah Negeri Kilongan. Peranan kepala sekolah sebagai ujung tombak pelaksanaan manajemen berbasis sekolah belum dilaksanakan sebagaimana mestinya. Hal tersebut disebabkan oleh faktor pekerjaan dan penciptaan hubungan antara kepala sekolah dengan guru serta keadaan sarana dan prasarana yang kurang mendukung berlangsungnya suatu kegiatan belajar mengajar.

\section{Rumusan Masalah}

Adapun yang menjadi masalah dalam penelitian ini berdasarkan latar belakang tersebut di atas adalah sebagai berikut :

1. Bagaimanakah kepemimpinan kepala sekolah di MIN Kilongan?

2. Bagaimanakah sistem yang diterapkan dalam kepemimpinan kepala sekolah di MIN Kilongan?

\section{Tujuan Dan Kegunaan Penelitian}

Tujuan penelitian ini adalah untuk mengetahui kepemimpinan kepala sekolah di MIN Kilongan.

Adapun kegunaan dari penelitian ini adalah sebagai berikut :

1. Secara teoritis, agar dapat bermanfaat sebagai bahan informasi bidangpendidikan bagi kalangan akademik guna memperkaya khasanah hasil-hasil penelitiannya khususnya pada Fakultas Keguruan dan Ilmu Pendidikan dan Fakultas Agama Islam Universitas Muhammadiyah Luwuk .

2. Secara praktis, agar dapat dijadikan sebagai bahan masukan kepada kepala-kepala sekolah dan Dinas Pendidikan dan Pengajaran Kabupaten Banggai dalam menetapkan kebijakan pengembangan mutu sekolah.

\section{METODE PENELITIAN}

\section{Variabel Penelitian}

Penelitian ini hanya menggunakan satu macam variabel yaitu yaitu variabel Peranan kepemimpinan kepala sekolah di MIN Kilongan .

\section{Desain Penelitian}

Penelitian ini adalah penelitian deskriptif yang bertujuan untuk menggambarkan bagaimana Peranan Kepala Sekolah. Penelitian ini merupakan penelitian eks post facto dimana desain 
penelitiannya bersifat kualitatif. Dalam hal ini penelitian yang digunakan adalah dirancang untuk mengetahui kepemimpinan Kepala Sekolah di Madrasah Ibtidaiyah Negeri (MIN) Kilongan.

\section{Defenisi Operasional}

Peranan Kepala Sekolah adalah serangkaian tindakan yang dilakukan oleh kepala sekolah MIN Kilongan untuk melaksanakan perencanaan, keterampilan komunikasi, pomberdayaan sumber daya manusia dan penciptaan budaya positif di lingkungan MIN Kilongan sehingga terwujud tujuan sekolah.

\section{Indikator}

Dari pengertian tersebut dapatlah dikembangkan beberapa sub variabel dari variabel peranan kepemimpinan kepala sekolah tersebut di atas, yaitu :

a. Pembinaan disiplin adalah kemampuan untuk membantu guru dan staf dalam rangka mengembangkan pola dan standar yang dijadikan acuan dalam rangka melaksanakan tugas-tugas pokok kepala sekolah.

Indikatornya adalah :

o Penegakkan aturan sekolah

- Keterampilan berkomunikasi.

- Bersikap positif dan bertanggung jawab.

b. Meningkatkan motivasi adalah kemampuan untuk memberikan dorongan kepada guru dan staf untuk bertugas secara maksimal.

Indikatornya adalah :

- Minat dan perhatian

- Suasana kerja

- Kewenangan dan tanggung jawab

- Diterima oleh kelompok

c. Penghargaan adalah simbol atau lambang yang diterima oleh guru dan staf oleh karena prestasi yang dibuatnya.
Indikatornya adalah :

- Insentif yang diterima

- Promosi jabatan

- Pengembangan guru dan staf

\section{Pengukuran Variabel}

Setiap kuisioner berisi pernyataan positif. Arah dan pemberian skor untuk pernyataan ini adalah skor tertinggi pada daerah yang jawaban yang sangat setuju dan yang terendah berada pada daerah jawaban yang sangat tidak setuju. Pemberian bobot untuk setiap jawaban menggunakan Skala Likert berbentuk nomor urut $1-5$ dengan alternatif jawaban sebanyak 5 (lima) item, yaitu sebagai berikut :

1. Sangat Setuju (SS) $=5$

2. Setuju (S) $=4$

3. Ragu-Ragu (RR) $=3$

4. Tidak Setuju (TS) $=2$

5. Sangat Tidak Setuju $($ STS $)=1$

\section{Populasi dan Sampel}

\section{Populasi}

Adapun yang menjadi populasi dalam penelitian ini adalah semua guru, pegawai tata usaha yang terlibat langsung dalam kegiatan belajar mengajar dan kegiatan administrasi dalam rangka membantu kepala sekolah di MIN Kilongan, yang berjumlah 18 (delapan) orang, yang terdiri dari 1 orang kepala sekolah, 12 orang guru dan 5 orang staf administrasi.

\section{Sampel}

Sampel yang baik adalah sampel yang representatif mewakili populasi. Berapa jumlah anggota sampel yang digunakan sebagai sumber data sangat tergantung pada tingkat kepercayaan yang dikehendaki.

Sampel akan diambil dari seluruh populasi yang ada, yaitu sebanyak 18 orang dengan jumlah sebagai berikut :

- Unsur pimpinan : 1 orang

- Staf pengajar : 12 orang

- Staf administrasi : 5 orang. 


\section{Jenis dan Sumber Data}

1. Data Primer

Data primer adalah data yang diperoleh langsung dari obyek penelitian melalui penelitian lapangan (field research). Penulis secara langsung mengadakan pengamatan sekaligus mengumpulkan sejumlah data di sekolah MIN Kilongan . Hal ini dimaksudkan untuk mengetahui lebih dekat permasalahan yang akan dibahas.

2. Data Sekunder

Data sekunder adalah data yang bersumber dari penelitian kepustakaan (library research). Penulis berusaha memperoleh data dengan menggunakan sumber dari beberapa literatur, majalah, dan membaca buku-buku yang berhubungan dengan masalah-masalah yang akan dibahas dalam penelitian ini.

Prosedur Pengumpulan dan Teknik Analisis Data

1. Prosedur Pengumpulan Data

Untuk mengumpulkan data yang dibutuhkan dalam penelitian ini maka digunakan metode :Studi Kepustakaan, yaitu dalam pengumpulan data penulis melakukan telaah dan mempelajari tulisan-tulisan, dokumen-dokumen yang dapat dijadikan rujukan serta referensi yang berhubungan dengan judul penelitian. Penelitian Lapangan yaitu dengan menggunakan teknik :

a. Observasi / pengamatan

Metode ini dipergunakan sebagai salah satu piranti dalam pengumpulan data berdasarkan pengamatan secara langsung terhadap permasalahan yang diteliti

b. Wawancara

Melalui teknik ini penulis mengadakan dialog secara langsung untuk memperoleh informasi dari responden terpilih dalam menghimpun informasi yang relevan dengan judul penelitian. c. Angket/ kuisioner

Teknik ini merupakan teknik pengumpulan data melalui formulirformulir yang berisi pertanyaanpertanyaan yang diajukan secara tertulis pada guru, penjaga sekolah, dan pegawai administrasi. Skala pengukurannya menggunakan Skala Likert untuk mendapatkan jawaban atau tanggapan dan informasi yang diperlukan oleh peneliti.

2. Teknik Analisis Data

Berdasarkan masalah pokok, tujuan penelitian dan hipotesis yang telah dikemukakan maka metode analisis untuk pembuktian hipotesis digunakan melalui analisis kualitatif dengan pendekatan peranan kepala sekolah MIN Kilongan yang diukur berdasarkan kemajuan prestasi belajar peserta didik. Dalam penelitian ini akan digunakan teknik statistik deskriptif untuk menganalisa data baik primer maupun sekunder. Teknik statisitik yang digunakan adalah analisis presentase yang disajikan dalam bentuk tabel distribusi frekuensi baik dengan angka maupun dengan presentasenya. Pertanyaan angket yang menggunakan jawaban 5 pilihan, masing-masing diberi nilai :
a. Bobot $=5$
b. Bobot $=4$
c. Bobot $=3$
d. Bobot $=2$
e. Bobot $=1$

Untuk menghitung skor yaitu dengan cara menjumlahkan seluruh hasil perkalian antara skor dengan pilihan frekuensi :

1. Skor $=$ Bobot $X$ Frekuensi

2. Untuk menghitung rata-rata sub indikator dari setiap variabel maka digunakan formula sebagai berikut :

$$
\text { Rata }- \text { RataSkor }=\frac{S k o r}{N}
$$


3. Rata-Rata Prosentase $=$

$$
\frac{\text { Rata }- \text { RataSkorX100 }}{\text { BanyaknyaPilihan }}
$$

Pengukuran variabelnya menggunakan skala normal sebagaimana dikemukakan oleh Suharsimi Arikunto (1998:246) bahwa :

"Kadang-kadang pencarian presentase dimaksudkan untuk mengetahui status sesuatu yang dipersentasekan dan disajikan tetap berupa persentase. Tetapi kadang-kadang sesudah sampai pada persentase lalu ditafsirkan dengan kalimat yang bersifat kualitatif, misalnya baik (76\%-100\%), cukup (56\%-75\%), kurang baik (40\%-55\%), tidak baik (kurang dari 40\%)."

Berpedoman pada pendapat di atas, maka penulis menetapkan standar atau kriteria untuk mengukur indikator dalam penelitian ini adalah sebagai berikut :

1. Sangat memuaskan bila rata-rata prosentase, $76 \%-100 \%$;

2. Cukup memuaskan bila rata-rata prosentase, 56\%-75\%;

3. Kurang memuaskan bila rata-rata prosentase, $40 \%-55 \%$; dan

4. Tidak memuaskan bila rata-rata prosentase, kurang dari $40 \%$.

\section{HASIL PENELITIAN DAN PEMBAHASAN}

Data yang disajikan dalam bab ini adalah hasil penelitian tentang peranan kepemimpinan kepala sekolah di MIN Kilongan Kecamatan Luwuk.Untuk mengolah data di atas, digunakan analisis persentase berdasarkan jawaban yang diberikan oleh responden, kemudian disajikan dalam bentuk tabel distribusi frekuensi. Adapun yang menjadi Indikator Peranan kepemimpinan kepala sekolah MIN Kilongan yaitu sebagai berikut :

\section{Pembinaan Disiplin}

Berdasarkan pengolahan angket tentang tanggapan responden terhadap kepemimpinankepala sekolahdalam aspek pembinaan disiplin diMadrasah Ibtidaiyah Negeri (MIN) Kilongan Kecamatan Luwuk Kabupaten Banggai, maka dapat ditampilkan rekapitulasi indikator kepemimpinan kepala MIN Kilongan tentang sikap pembinaan disiplin sebagai kepala sekolah sebagaimana yang disajikan pada tabel 1.

Dari Tabel 1 tersebut dapat diketahui bahwa sikap kepala sekolah dalam pembinaan disiplin "memuaskan" dengan angka skor ratarata 4,86. Angka tersebut memberi makna bahwa 97,2 \%, atau hanya 17 dari 18 orang responden menyatakan bahwa aspek disiplin kepala sekolah "sangat memuaskan".

2. Peningkatan Motivasi Kerja Guru Dan Pegawai Tata Usaha

Berdasarkan olahan angket tanggapan responden tentang kepala sekolah memberikan peningkatan motivasi kerja guru dan tata usaha, berikut ditampilkan rekapitulasi indikator kepala sekolah dalam aspek peningkatan motivasi kerja guru dan tata usaha sebagaimana tabel 2 .

Dari Tabel 2 tersebut dapat diketahui bahwa sikap kepala sekolah dalam aspek peningkatan motivasi kerja guru dan tata usaha “ memuaskan" dengan angka skor ratarata 4,86. Angka tersebut memberi makna bahwa 97,2\%, atau 17 dari 18 orang responden menyatakan bahwa sikap kepala sekolah dalam aspek peningkatan motivasi kerja guru dan tata usaha "sangat memuaskan". 
Tabel 1.

Hasil Angket Kepemimpinan Kepala Sekolah Di MIN Kilongan Dalam Aspek Pembinaan Disiplin

\begin{tabular}{|c|c|c|c|c|c|c|c|c|c|c|c|c|}
\hline \multirow{2}{*}{$\begin{array}{l}\text { No. } \\
\text { Resp }\end{array}$} & \multicolumn{10}{|c|}{ Jawaban Responden Untuk Item } & \multirow[b]{2}{*}{ Jum } & \multirow{2}{*}{$\begin{array}{c}\text { RataR } \\
\text { ata }\end{array}$} \\
\hline & (1) & (2) & (3) & (4) & $(5)$ & $(6)$ & 7 & 8 & 9 & 10 & & \\
\hline 1 & 5 & 5 & 5 & 5 & 5 & 5 & 5 & 5 & 5 & 2 & 47 & 4,7 \\
\hline 2 & 5 & 5 & 5 & 5 & 5 & 2 & 5 & 5 & 5 & 5 & 47 & 4,7 \\
\hline 3 & 5 & 5 & 5 & 5 & 5 & 5 & 5 & 5 & 5 & 5 & 50 & 5 \\
\hline 4 & 5 & 5 & 5 & 5 & 5 & 5 & 5 & 4 & 5 & 5 & 49 & 4,9 \\
\hline 5 & 4 & 5 & 5 & 5 & 5 & 5 & 5 & 5 & 5 & 5 & 49 & 4,9 \\
\hline 6 & 5 & 5 & 5 & 3 & 5 & 5 & 5 & 5 & 5 & 5 & 48 & 4,8 \\
\hline 7 & 5 & 5 & 5 & 5 & 5 & 5 & 5 & 5 & 5 & 4 & 49 & 4,9 \\
\hline 8 & 5 & 5 & 4 & 5 & 5 & 5 & 5 & 5 & 5 & 5 & 49 & 4,9 \\
\hline 9 & 5 & 5 & 5 & 5 & 5 & 5 & 3 & 5 & 5 & 5 & 48 & 4,8 \\
\hline 10 & 5 & 5 & 5 & 5 & 5 & 5 & 5 & 5 & 5 & 3 & 48 & 4,8 \\
\hline 11 & 5 & 5 & 5 & 4 & 5 & 5 & 5 & 5 & 5 & 5 & 49 & 4,9 \\
\hline 12 & 4 & 5 & 5 & 5 & 5 & 5 & 5 & 5 & 5 & 5 & 49 & 4,9 \\
\hline 13 & 5 & 5 & 5 & 4 & 4 & 5 & 5 & 5 & 5 & 5 & 48 & 4,8 \\
\hline 14 & 5 & 4 & 5 & 5 & 5 & 5 & 2 & 5 & 5 & 5 & 46 & 4,6 \\
\hline 15 & 5 & 5 & 5 & 5 & 5 & 5 & 5 & 5 & 5 & 5 & 50 & 5 \\
\hline 16 & 5 & 5 & 5 & 5 & 5 & 5 & 5 & 5 & 5 & 5 & 50 & 5 \\
\hline 17 & 5 & 5 & 5 & 5 & 5 & 4 & 5 & 5 & 5 & 5 & 49 & 4,9 \\
\hline 18 & 5 & 5 & 5 & 5 & 5 & 5 & 5 & 5 & 5 & 5 & 50 & 5 \\
\hline Jum & 88 & 89 & 89 & 86 & 89 & 86 & 85 & 89 & 90 & 84 & 193 & 87.6 \\
\hline Skor & 4,88 & 4,94 & 4,94 & 4,77 & 4,94 & 4,77 & 4,72 & 4,94 & 5 & 4,66 & 10,72 & 4.86 \\
\hline$\%$ & 97.6 & 98.8 & 98,8 & 95,4 & 98.8 & 95,4 & 94,4 & 98.8 & 100 & 93,2 & 21,44 & 97.2 \\
\hline
\end{tabular}

Sumber : Data Primer

Tabel 2.

Hasil Angket Kepemimpinan Kepala Sekolah Di MIN Kilongan Dalam Aspek Peningkatan Motivasi Kerja Guru/ Tata Usaha

\begin{tabular}{|c|c|c|c|c|c|c|c|c|c|c|c|c|}
\hline \multirow{2}{*}{$\begin{array}{l}\text { No. } \\
\text { Resp }\end{array}$} & \multicolumn{10}{|c|}{ Jawaban Responden Untuk Item } & \multirow[b]{2}{*}{ Jum } & \multirow{2}{*}{$\begin{array}{l}\text { Rata } \\
\text { Rata }\end{array}$} \\
\hline & 11 & 12 & 13 & 14 & 15 & 16 & 17 & 18 & 19 & 20 & & \\
\hline 1 & 5 & 5 & 5 & 5 & 5 & 5 & 5 & 5 & 5 & 2 & 47 & 4,7 \\
\hline 2 & 5 & 5 & 5 & 5 & 5 & 2 & 5 & 5 & 5 & 5 & 47 & 4,7 \\
\hline 3 & 5 & 5 & 5 & 5 & 5 & 5 & 5 & 5 & 5 & 5 & 50 & 5 \\
\hline 4 & 5 & 5 & 5 & 5 & 5 & 5 & 5 & 4 & 5 & 5 & 49 & 4,9 \\
\hline 5 & 4 & 5 & 5 & 5 & 5 & 5 & 5 & 5 & 5 & 5 & 49 & 4,9 \\
\hline 6 & 5 & 5 & 5 & 3 & 5 & 5 & 5 & 5 & 5 & 5 & 48 & 4,8 \\
\hline 7 & 5 & 5 & 5 & 5 & 5 & 5 & 5 & 5 & 5 & 4 & 49 & 4,9 \\
\hline 8 & 5 & 5 & 4 & 5 & 5 & 5 & 5 & 5 & 5 & 5 & 49 & 4,9 \\
\hline 9 & 5 & 5 & 5 & 5 & 5 & 5 & 3 & 5 & 5 & 5 & 48 & 4,8 \\
\hline 10 & 4 & 5 & 5 & 5 & 5 & 5 & 5 & 5 & 5 & 5 & 49 & 4,9 \\
\hline 11 & 5 & 5 & 5 & 5 & 3 & 5 & 5 & 5 & 5 & 5 & 48 & 4,8 \\
\hline 12 & 5 & 5 & 5 & 5 & 5 & 5 & 5 & 5 & 5 & 5 & 50 & 5 \\
\hline 13 & 5 & 5 & 5 & 5 & 5 & 5 & 5 & 4 & 5 & 5 & 49 & 4,9 \\
\hline 14 & 4 & 5 & 5 & 5 & 5 & 5 & 5 & 5 & 5 & 5 & 49 & 4,9 \\
\hline 15 & 5 & 5 & 5 & 3 & 5 & 5 & 5 & 5 & 5 & 5 & 48 & 4,8 \\
\hline 16 & 5 & 5 & 5 & 5 & 5 & 5 & 5 & 5 & 5 & 4 & 49 & 4,9 \\
\hline 17 & 5 & 5 & 4 & 5 & 5 & 5 & 5 & 5 & 5 & 5 & 49 & 4,9 \\
\hline 18 & 5 & 5 & 5 & 5 & 5 & 5 & 3 & 5 & 5 & 5 & 48 & 4,8 \\
\hline Jum & 87 & 90 & 88 & 86 & 88 & 82 & 86 & 88 & 90 & 85 & 875 & 87,5 \\
\hline Skor & 4,83 & 5 & 4,88 & 4,77 & 4,88 & 4,55 & 4,77 & 4,88 & 5 & 4,72 & 48,61 & 4,86 \\
\hline$\%$ & 96,6 & 100 & 97,6 & 95,4 & 97,6 & 91 & 95,5 & 97,6 & 100 & 94.4 & 97.22 & 97.2 \\
\hline
\end{tabular}


3. Penghargaan Atas Prestasi Kerja Bawahan

Berdasarkan olahan angket tanggapan responden tentang kepala sekolah memberikan penghargaan atas prestasi kerja bawahannya dapat dilihat pada hasil angkat dibawah ini, berikut ditampilkan rekapitulasi indikator sikap kepala sekolah dalam aspek penghargaan atas prestasi kerja bawahanya sebagaimana tabel 3 .
Dari Tabel 3 tersebut dapat diketahui bahwa sikap kepala sekolah dalam aspek penghargaan atas prestasi kerja bawahannya "memuaskan" dengan angka skor rata-rata 4,83. Angka tersebut memberi makna bahwa $96,6 \%$, atau hanya 17 dari 18 orang responden menyatakan bahwa sikap kepala sekolah dalam memberikan penghargaan atas prestasi kerja bawahannya "sangat memuaskan".

Tabel 3

Hasil Angket Kepemimpinan Kepala MIN Kilongan

Dalam Aspek Penghargaan Atas Prestasi Kerja Bawahannya

\begin{tabular}{|c|c|c|c|c|c|c|c|c|c|c|c|c|}
\hline \multirow{2}{*}{$\begin{array}{c}\text { No. } \\
\text { Res }\end{array}$} & \multicolumn{10}{|c|}{ Jawaban Responden Untuk Item } & \multirow{2}{*}{ Rata } \\
\hline & 21 & 22 & 23 & 24 & 25 & 26 & 27 & 28 & 29 & 30 & Jum & Rata \\
\hline 2 & 5 & 5 & 5 & 5 & 5 & 5 & 5 & 5 & 5 & 2 & 47 & 4,7 \\
\hline 3 & 5 & 5 & 5 & 5 & 5 & 2 & 5 & 5 & 5 & 5 & 47 & 4,7 \\
\hline 4 & 5 & 5 & 5 & 5 & 5 & 5 & 5 & 5 & 5 & 5 & 50 & 5 \\
\hline 5 & 4 & 5 & 5 & 5 & 5 & 5 & 5 & 4 & 5 & 5 & 49 & 4,9 \\
\hline 6 & 5 & 5 & 5 & 3 & 5 & 5 & 5 & 5 & 5 & 5 & 48 & 4,8 \\
\hline 7 & 5 & 5 & 5 & 5 & 5 & 5 & 5 & 5 & 5 & 4 & 49 & 4,9 \\
\hline 8 & 5 & 5 & 4 & 5 & 5 & 5 & 5 & 5 & 5 & 5 & 49 & 4,9 \\
\hline 9 & 5 & 5 & 5 & 5 & 5 & 5 & 3 & 5 & 5 & 5 & 48 & 4,8 \\
\hline 10 & 5 & 5 & 5 & 5 & 5 & 5 & 5 & 5 & 5 & 3 & 48 & 4,8 \\
\hline 11 & 5 & 5 & 5 & 5 & 5 & 5 & 5 & 5 & 5 & 2 & 47 & 4,7 \\
\hline 12 & 5 & 5 & 5 & 5 & 5 & 2 & 5 & 5 & 5 & 5 & 47 & 4,7 \\
\hline 13 & 5 & 5 & 5 & 5 & 5 & 5 & 5 & 5 & 5 & 5 & 50 & 5 \\
\hline 14 & 5 & 5 & 5 & 5 & 5 & 5 & 5 & 4 & 5 & 5 & 49 & 4,9 \\
\hline 15 & 4 & 5 & 5 & 5 & 5 & 5 & 5 & 5 & 5 & 5 & 49 & 4,9 \\
\hline 16 & 5 & 5 & 5 & 3 & 5 & 5 & 5 & 5 & 5 & 5 & 48 & 4,8 \\
\hline 17 & 5 & 5 & 5 & 5 & 5 & 5 & 5 & 5 & 3 & 4 & 47 & 4,7 \\
\hline 18 & 5 & 5 & 4 & 5 & 5 & 5 & 5 & 5 & 5 & 5 & 49 & 4,9 \\
\hline Jum & 88 & 90 & 88 & 86 & 90 & 84 & 88 & 88 & 87 & 75 & 870 & 87 \\
\hline Skor & 4,88 & 5 & 4,88 & 4,77 & 5 & 4,66 & 4,88 & 4,88 & 4,83 & 4,16 & 48,33 & 4,83 \\
\hline$\%$ & 97,6 & 100 & 97,6 & 95.4 & 100 & 93,2 & 97,6 & 97,6 & 96,6 & 83,2 & 96.66 & 96,6 \\
\hline
\end{tabular}

Sumber : Data Primer

Berdasarkan hasil analisis data tersebut di atas, data yang dipaparkan mengenai kepemimpinan kepala sekolah di MIN Kilongan yang ditinjau dari tiga aspek kemudian penulis jabarkan dalam tabel berikut yang hasilnya merupakan kesimpulan dari keseluruhan aspek yang dikaji.
Tabel yang akan disajikan merupakan rekapitulasi dari keseluruhan angket yang telah disebarkan kepada responden. Secara lengkap rekapitulasi hasil angket tersebut penulis sajikan dalam tabel 4 . 
Tabel 4.

Rekapitulasi Hasil Angket Tentang Kepemimpinan Kepala MIN Kilongan

\begin{tabular}{|c|l|c|c|}
\hline No & \multicolumn{1}{|c|}{ Aspek } & Skor & Persentase \\
\hline 1 & Pembinaan Disiplin & 4,86 & 97,2 \\
\hline 2 & $\begin{array}{l}\text { Peningkatan Motivasi Kerja Guru Dan } \\
\text { Pegawai Tata Usaha }\end{array}$ & 4,86 & 97,2 \\
\hline 3 & Penghargaan Atas Prestasi Kerja Bawahan & 4,83 & 96,6 \\
\hline Total & 14,55 & 291 \\
\hline \multicolumn{2}{|c|}{ Rata-Rata } & 4,85 & 97 \\
\hline
\end{tabular}

Dari Tabel 4 tersebut dapat diketahui bahwa responden menyatakan bahwa kepemimpinan Kepala Sekolah di MIN Kilongan tergolong cukup memuaskan dengan perolehan skor 4,85 . Skor tersebut memberi makna bahwa $97 \%$, atau hanya 17 dari 18 orang responden menyatakan bahwa pola kepemimpinan Kepala sekolah di MIN Kilongan"sangat memuaskan" bagi guru dan staf tata usaha yang menjadi bawahannya.

\section{KESIMPULAN}

Berdasarkan hasil pengolahan dan analisa data di atas maka dapat ditarik kesimpulan sebagai berikut :

1. Kepemimpinan Kepala sekolah di MIN Kilongan tergolong baik dan dianggap memuaskan semua pihak yang berada di dalam lingkungan sekolah.

2. Upaya yang

dilakukan oleh Kepala Sekolah untuk meningkatkan motivasi guru dan tata usaha antara lain dengan adanya kebebasan guru dan tata usaha dalam pengembangan inovasi pembelajaran serta pemenuhan segala fasilitas pembelajaran dan upaya-upaya tersebut dianggap cukup memuaskan bagi guru dan tata usaha.
3. Penghargaan atas prestasi bawahan dilakukan oleh kepala sekolah dengan memberikan reward serta promosi jabatan dan pemberian nilai yang sesuai dengan kinerjanya. Upaya tersebut menurut responden dianggap memuaskan bagi bawahannya.

\section{SARAN}

Berdasarkan hasil penelitian, dan kesimpulan yang telah dikemukakan maka diajukan saran-saran sebagai berikut :

1. Kepala Sekolah hendaknya lebih meningkiatkan etos kerja yang selamaini sudah cukup baik, dan tidak dianggap apa yang dilakukan oleh guru, bukia sesuatu yang dilakukan untuk mencari kesalahan, tetapi sebagai bahan koreksi konstruktif agar dapat berjalan sesuai dengan apa yang diharapkan.

2. Disarankan kepada Kepala Sekolah untuk lebih meningkatkan frekuensi supervisi di sekolah tanpa mendelegasikan kepada pihak lain untuk mengurangi unsur subjektivitas dari supervisor. 


\section{DAFTAR PUSTAKA}

Agus, Sujanto. 1988.Psikologi Perkembangan.Cet. I. Surabaya : Aksara Baru

Ahmad, Rohani. 1996.Pedoman Penyelenggaraan Administrasi di Sekolah.Jakarta :Bumi Aksara

Arikunto, Suharsimi. 1992. Prosedur Penelitian. Suatu Pendekatan Praktek,Jakarta :Bumi Aksara

Ary H. Gunawan. 1996. Administrasi Sekolah Administrasi Pendidikan,Jakarta :Rineka Cipta

Bafadal, Ibrahim. 1992.Supervisi Pengajaran Teori dan Aplikasinya Dalam Membina Profesional Guru.Cet. IJakarta :Bumi Aksara

Daryanto . H. M. 2001. Administrasi Pendidikan,Jakarta :Penerbit Rineka Cipta

Gunarsa, Singgih D. 1991.Psikologi Anak. Remaja dan Keluarga. Cet. II BPK Gunung Mulia : Jakarta.

Handari Nawawi. 1989. Administrasi Pendidikan,Jakarta :Gunung Agung

Hariwung, A. J. 1989. Supervisi Pendidikan,Jakarta :P2LPTKJ Dirjen Dekdikbbud

Imam supardi. 1988. Dasar-dasar Administrasi Pendidikan, Jakarta :Bumi Aksara

Kartono. Kartini. 1992.Psikologi Anak, Bandung :Indah Jaya.

Lawalata, P. M. 1986, Psychologi Pendidika,Jakarta :CV. Rajawali.

Margono. S. 2003.Metodologi Penelitian Pendidikan.Cet III. Jakarta.Rineka Cipta

Wayan Nurkancana. 1983.Evaluasi Pendidika, Surabaya : Usaha Nasional.

Drs. Riduwan, M.B.A. 2002. Skala Pengukuran Variabel-Variabel Penelitian. Cet. II. Bandung : CV. Alfabeta. 